\title{
In vitro characterization of spheres derived from colorectal cancer cell lines
}

\author{
AGATA OLEJNICZAK ${ }^{*}$, MAGDALENA SZARYŃSKA* and ZBIGNIEW KMIEĆ \\ Department of Histology, Medical University of Gdansk, 80-210 Gdansk, Poland
}

Received August 29, 2017; Accepted October 8, 2017

DOI: 10.3892/ijo.2017.4206

\begin{abstract}
Spherical cultures (SCs) can be regarded in cancer research as a link between in vitro investigations on cancer lines and in vivo studies of tumor development. SCs are believed to mimic tumor architecture and to be enriched in cancer stem cell-like cells (CSC-like cells). In the present study we characterized colonospheres derived from colorectal cancer (CRC) cell lines, and we confirmed the ability of HCT116 and HT29 cell lines to form spheres within serum-free medium, however, the detailed analysis presented the major differences concerning their characteristics including morphology, phenotype, proliferative potential, distribution in the cell cycle phases and spherogenicity. Moreover, after we magnetically separated $\mathrm{CD}_{133^{+}}$and $\mathrm{CD} 133^{-}$cells we could conduct the analogical analysis as we performed for the original cells. We observed that all cellular fractions unveiled sphere formation capacity, even when cultured in limited number of cells per well and only SCs originated from $\mathrm{CD} 133^{+}$fraction resembled morphologically the parental spheres. Both $\mathrm{CD} 133^{+}$and $\mathrm{CD} 133^{-}$subsets derived from HCT116 line were more enriched in cells in G0/G1 phase of the cell cycle in comparison to their HT29 analogues. Additionally, proliferative potential also varied amongst all studied fractions. Surprisingly, 3-D invasion assay revealed that only HCT116-derived populations were able to migrate into extended regions of Matrigel Matrix confirming their higher aggressiveness. Our results provided comprehensive characterization of CRC cell lines culture in adherent and spherical forms and, what seems to be the most advantageous, the
\end{abstract}

Correspondence to: Dr Magdalena Szaryńska,Histology Department, Medical University of Gdansk, Debinki 1, 80-210 Gdansk, Poland E-mail:mszarynska@gumed.edu.pl

*Contributed equally

Abbreviations: 7-AAD, 7-aminoactinomycin D; BMI-1, B lymphoma Mo-MLV insertion region 1 homolog; CRC, colorectal cancer; CSC, cancer stem cell; EpCAM, epithelial cell adhesion molecule; LGR-5, leucine-rich repeat-containing G-protein coupled receptor 5; MFI, median fluorescence intensify; SC, spherical culture; SCM, stem cell medium

Key words: colorectal cancer cell lines, HCT116, HT29, spherical cultures, cancer stem cells comparison of two distinct fractions after magnetic separation. As we found the specific features of cells presented line- and expansion mode-dependency, thus, such complete description might appear crucial before CRC lines would be involved into sophisticated assays, especially focused on potentially novel therapeutic agents targeting CSC-like cells.

\section{Introduction}

Cancer is among the leading causes of death worldwide and colorectal cancer (CRC) is the third most frequently diagnosed cancer type (1). Despite the fact that some progress has been made in recent years, colorectal cancer progression, metastasis and treatment still constitute essential medical problems. Increasing evidence suggests that CRC may develop according to the hierarchical model of carcinogenesis which postulates existence of small sub-population of poorlydifferentiated, self-renewable cancer stem cells (CSCs), also called tumor initiating cells (TICs) or cancer stem cell-like cells (CSC-like cells) (2). CSC-like cells have been induced in the SW480 colorectal cell line by the transduction of OCT3/4, SOX2, KLF4 genes using retrovirus vectors $(3,4)$. Such a transformation may be caused also by alterations in the cell microenvironment and may depend on transforming growth factor- $\beta$ (TGF- $\beta$ ) signaling (5). It was postulated that TGF- $\beta$ through activation of epithelial mesenchymal transition (EMT) may act by retaining of dynamic equilibrium between CSC-like cells and non-CSC-like cells within human colorectal and breast cancer lines (6).

Lapidot et al (7) were the first to describe characteristics of cells capable of developing acute myeloid leukemia (AML) after transplantation into severe combined immune-deficient (SCID) mice, which were suggested to be CSC-like cells. Over the years, CSC-like cells were proven to exist in many solid tumors including breast $(8,9)$, pancreas $(10,11)$, skin $(12)$, lung (13), glioblastoma $(14,15)$, prostate $(16)$, and colon cancers $(17,18)$ as well as in brain and glioblastoma $(19,20)$. CSC-like cells are capable of self-renewal and differentiation into non-tumorigenic cell progeny and are resistant to conventional therapeutic procedures. Due to their specific properties and insensitivity to chemo- and radiotherapy, CSC-like cells are believed to be a source of cancer recurrence (21-23). Therefore, targeting CSC-like cells or their niches may lead to eradication of cancer cells, reduction of tumor relapse risk and improved prognosis for CRC patients. 
Isolation of the CSC-like cells from the total cancer cell population is essential for circumstantial studies on their participation in cancer progression, metastasis and drug resistance. Their detection is based on cytological sorting, morphological and biochemical features as well as xenotransplantation assays (24). The identification of specific surface biomarkers is one of the most commonly used types of CSC-like cell analysis. To distinguish colon CSC-like cell population from other tumor cells Ricci-Vitiani et al (17) used as their marker CD133 protein, known also as a prominin-1. $\mathrm{CD}_{133^{+}}$population was found to account for approximately $2.5 \%$ of all cancer cells in CRC samples after tissue dissociation. Expression of CD133 protein only in cell populations capable of sphere formation, self-renewal and resistant to chemotherapeutics confirmed its role as a putative CSC-like cell marker by other groups $(18,25,26)$. They found expression of CD133 on the surface of CSC-like cells in brain, pancreatic, gastric and gallbladder cancers. However, Shmelkov et al (27) reported that both, $\mathrm{CD}_{133^{+}}$and $\mathrm{CD} 133^{-}$metastatic colon subsets were capable of tumor initiation in the mouse model. CD133- subset derived from metastatic CRC was capable of long-term growth in a xenograft model within NOD/SCID mice and appeared to be more aggressive in comparison to $\mathrm{CD}_{133^{+}}$population. Moreover, the phenotypic analysis of CD133- cells confirmed the expression of next CSC-like marker, CD44 molecule, which correlated with the formation of more aggressive tumors (27).

It has been proposed recently that the usage of spherical cultures (SCs) presents a more adequate tool for culturing and analysis of stem cells. This concept is based on anchorageindependent properties of CSC-like cells which are capable of surviving after being detached from niche elements and forming next cellular aggregates floating freely in the serumfree medium. That is contrary to the non-stem cancer cells population which undergo anoikis under the same culture conditions (28-31). These three-dimensional (3-D) models gained popularity in the field of breast (32), lung (33), ovarian (34) and colon $(29,31)$ cancer research. In the twodimensional (2-D) systems, cells are grown as monolayer, lacking specific interactions that are present in native tumors, thus, 2-D cultures poorly mirror the complexity of cancer microenvironment. Hence, multicellular spheroid model seems to partially simulate naturally-occurring heterogeneity in regard to cellular morphology (35). Heterogeneous exposure to oxygen, nutrients, physical and chemical stresses, and specific gene expression (29,36-38). SCs are more likely to be engaged in some functional assays since they more adequately support CSC-like cell properties $(25,30,31,38)$.

Although HCT116 and HT29 cancer cell lines belong to the most often utilized CRC model cells in 2-D cultures, their properties when cultured in adherent and spherical models have not yet been fully compared. Therefore, we decided to investigate the biological characteristics of colonospheres derived from HCT116 and HT29 cell lines in vitro and verify the influence of the culture conditions on cancer cell properties, and especially number and features of CSC-like cells. Additionally, to fully evaluate the features of SCs cells, we performed magnetic cell sorting based on the presence of the CD133 protein on the cell surface. The literature is lacking such comprehensive description thus we wish to fulfill this field of knowledge.

\section{Materials and methods}

HT29 and HCT116 monolayer cell culture. Both, HT29 and HCT116, human adenocarcinoma colorectal cell lines were originally purchased from the American Type Culture Collection (ATCC; Manassas, VA, USA). All experimental chemicals were purchased from Sigma-Aldrich (Poznan, Poland). The cells were cultured in medium recommended by the manufacturer, McCoy's medium supplemented with $10 \%$ fetal bovine serum (FBS), $1 \%$ penicillin-streptomycin and $2 \mathrm{mM} \mathrm{L}$-glutamine and incubated at $37^{\circ} \mathrm{C}$ under a humidified atmosphere of $5 \% \mathrm{CO}_{2}$. The cells were subcultured by trypsinEDTA treatment when they achieved $\sim 80 \%$ confluency and the medium was renewed 3 times per week.

Colonosphere-derived HCT116 and HT29 cell lines. All experimental chemicals were purchased from Sigma-Aldrich, except for growth factors, which were purchased from R\&D Systems/Biokom (Warszawa, Poland). Cells were originally cultivated in PCM, trypsinized, washed twice in phosphatebuffered saline (PBS) and maintained in serum-free stem cell medium containing Dulbecco's modified Eagle's medium (DMEM)-F12 supplemented with ITS Liquid Media Complement, $5 \mathrm{mM}$ HEPEs, $4 \mathrm{mg} / \mathrm{ml}$ BSA, $2 \mathrm{nM}$ L-glutamine, $3 \mathrm{mg} / \mathrm{ml}$ glucose, $20 \mathrm{ng} / \mathrm{ml}$ EGF, $20 \mathrm{ng} / \mathrm{ml}$ bFGF and antibiotic antimycotic solution. This medium will be referred to as stem cell medium (SCM). For characterization purposes, we only used 5-6 passage SC within the present study.

Phenotypic flow cytometric analysis. Colonospheres were first washed in PBS-EDTA (Sigma-Aldrich) medium for 5 min, to obtain single-cell suspension. CRC line cells and cells from colonospheres were stained with the following monoclonal antibodies: anti-CD29-APC (clone MAR4, IgG1, $\kappa$ ), anti-CD44-FITC (clone, G44-26, IgG2b, $\kappa$ ), antiEpCAM-FITC (clone EBA-1, IgG1), and anti-LGR5-Biotin (clone 4D11F8, IgG2b, $\kappa$ ) coupled with streptavidin-APC (BD Biosciences, San Jose, CA, USA). Anti-CD133/2-PE (clone 293C3, IgG2b, א) monoclonal antibody was purchased from Miltenyi Biotec (Bergisch Gladbach, Germany). After 30 min of incubation in the dark in room temperature (RT) samples were fixed and prepared for further analysis. Intracellular staining was performer for anti-BMI-1-FITC (clone P51-311, IgG1, $\kappa$ ) according to the manufacturer's instructions (BD Biosciences). Cells were mixed with warm fixation buffer in volume ratio $1: 1$ and incubated for $10 \mathrm{~min}$ in $37^{\circ} \mathrm{C}$. In the next steps, cells were centrifuged at $250 \mathrm{x}$ g for $10 \mathrm{~min}$ and the supernatant was discarded. Pellet was washed with chilled stain buffer and centrifuged under same conditions to remove supernatant. Cold Perm buffer was added to the pellet while vortexing. Cells were incubated on ice for $30 \mathrm{~min}$, centrifuged and washed twice with staining buffer. Cells $\left(1 \times 10^{7}\right)$ were suspended in $1 \mathrm{ml}$ of stain buffer, divided into separated testtubes and stained with anti-BMI-1. Next steps were analogical like in an extracellular staining procedure presented above. Flow cytometric analysis was performed using FACSCalibur flow cytometer (BD Biosciences).

Cell death assay. The 7-aminoactinomycin D (7-AAD) dye (BD Biosciences), a compound binding to the DNA of impaired 
cells, was used for death cell evaluation. After adding $10 \mu \mathrm{m}$ of Via Probe samples were incubated for $30 \mathrm{~min}$, washed and re-suspended in PBS prior to cytometric analysis.

Apoptosis assay. Analysis was based on changes of phosphatidylserine localization within cell membrane using Annexin V-FITC apoptosis detection kit I (BD Biosciences) according to the manufacturer's instructions. Cells $\left(1 \times 10^{6}\right)$ were suspended in $1 \mathrm{ml}$ of binding buffer. A total of $5 \mu \mathrm{l}$ Annexin V-FITC and $5 \mu \mathrm{l}$ of PI were added, gently pipetted and incubated for $15 \mathrm{~min}$ in RT in the dark. After that time, $400 \mu \mathrm{l}$ binding buffer was added and flow cytometric analysis was performed within $1 \mathrm{~h}$.

Magnetic cell sorting based on MACS technology. The procedure was conducted according to the manufacturer's recommendation (Miltenyi Biotec). In brief, $20 \mu \mathrm{l}$ of Blocking Reagent and $20 \mu 1$ of CD133 MicroBeads Tumor Tissue were added to cells suspended in buffer composed of PBS (Sigma-Aldrich), 0.5 M EDTA (Sigma-Aldrich) and 10\% BSA (Sigma-Aldrich) and incubated for $15 \mathrm{~min}$. Cells were washed and $10 \mu \mathrm{l}$ of Labeling Check Reagent-PE was added and was incubated for $5 \mathrm{~min}$. Labeled cells were washed and re-suspended in proper amount of the buffer. Cell suspension was applied onto the MS Column which was washed three times with buffer. Cells within flow-through were collected. The purity of isolated subpopulation was checked by addition of CD133/2 (293C3) antibody and flow cytometric analysis.

Cell cycle analysis. Cells $\left(1 \times 10^{7}\right)$ after 7 days of culturing were pipetted, washed twice in PBS (Sigma-Aldrich), fixed on $70 \%$ ethanol at $-20^{\circ} \mathrm{C}$. Within 2 weeks, cells were centrifuged, suspended in staining buffer composed of PBS, propidium iodide (PI) $(50 \mu \mathrm{g} / \mathrm{ml})$ and RNase $(25 \mu \mathrm{g} / \mathrm{ml})$ (both from Sigma-Aldrich) for $30 \mathrm{~min}$ in the dark at $37^{\circ} \mathrm{C}$. Samples were analyzed using FACSCalibur flow cytometer (BD Biosciences).

Cell growth and proliferation assay. Adherent cells were seeded in cell culture flask with vented cap in PCM and HCT116- and HT29-derived spheres in 24-well plates in SCM. After every passage, cells were dissociated into single-cell suspension and counted.

Proliferation assay. Proliferation abilities were measured based on the CellTrace ${ }^{\mathrm{TM}}$ Cell Proliferation kit (Invitrogen; Thermo Fisher Scientific, Inc., Carlsbad, CA, USA) according to the manufacturer's protocol which differs among adherent and spherical cells. Spherical cells in suspension were incubated with $5 \mu \mathrm{M}$ CellTrace-CFSE Dye for $20 \mathrm{~min}$ at $37^{\circ} \mathrm{C}$, protected from light. Afterwards, free dye was removed by addition of culture medium and centrifugation. Pellet cells were re-suspended in complete SCM and proceeded with 7 days incubation and analysis. Adherent cells were not trypsinized; old medium was removed and replaced with $5 \mu \mathrm{M}$ CellTrace-CFSE buffer and incubated in the dark. Then, the solution was removed, the cells were washed twice with PBS and replaced with fresh medium for 7 days. At day 0 and 7 cells were analyzed by the FACSCalibur flow cytometer (BD Biosciences).
Table I. Sizes of the colonospheres.

\begin{tabular}{lcc}
\hline & $\begin{array}{c}\text { HCT116-derived } \\
\text { spheres }\end{array}$ & $\begin{array}{c}\text { HT29-derived } \\
\text { spheres }\end{array}$ \\
\hline Length $(\mu \mathrm{m})$ & $300.19 \pm 63.08$ & $186.24 \pm 55.98$ \\
Width $(\mu \mathrm{m})$ & $270.23 \pm 46.59$ & $167.82 \pm 46.74$ \\
\hline
\end{tabular}

Spheres sizes were measured at given time-points during expansion. Results obtained from 3 independent experiments. At least 5 colonospheres from each experiment were measured. Results are expressed as mean \pm SEM.

Dilution assay. Cells after magnetic sorting were seeded at different density by using serial dilution method beginning with 2,500 cells/well and finishing with 10 cells/well. Cells were cultured in 24-well plates, dedicated to non-adherent cells, in SCM. After 7 days, cells were dissociated into single-cell suspension, stained with Trypan blue (Sigma-Aldrich) and counted.

3-D sphere invasion assay. After 7 days of culturing, formed spheres were taken and the diameters were measured. Spheres were suspended in a mixture of Matrigel ${ }^{\mathrm{TM}}$ Matrix growth factor reduced matrix (BD Biosciences) and DMEM/F12 medium (Sigma-Aldrich) in ratio 1:4 on ice and transferred onto a 24-well plate. Invasion was monitored by measuring the maximal outgrowth of the sphere diameter after 8 days. Photographs were taken with the use of inverted microscope Olympus CKX53 coupled with digital camera Olympus SC50 (Olympus Corp., Tokyo, Japan).

Statistical analysis. Data were computed using the GraphPad Prism ver. 6.05 (GraphPad Software, Inc., San Diego, CA, USA) and software Statistica 12 (StatSoft, Kraków, Poland). Statistical significance of differences between the mean values was based on non-parametric tests and assessed by the MannWhitney U, the Kruskal-Wallis analysis of variance (ANOVA) and the Spearman's rank correlation. Values of $\mathrm{P}<0.001$ or $\mathrm{P}<0.05$ were considered as statistically significant. Within the present study, data from at least 3 independent experiments have been analyzed to verify reproducibility of the results. The data are presented as the means \pm standard error of the mean (SEM).

\section{Results}

Establishing of spherical models derived from HCT116 and HT29 cells. HCT116 and HT29 cell lines cultured in selective conditions of stem cell medium (SCM) formed spheres (Fig. 1); however, colonospheres from both lines displayed morphological differences. HCT116 cells formed larger spheres with diameters varying from 150 up to $400 \mu \mathrm{m}$. Shape of the HCT116-derived spheres was spherical with regular, continuous and aquiline contour, which can be described as compact tumor packaging. In comparison, the HT29-derived spheres were smaller (100-300 $\mu \mathrm{m})$, their outline was less regular and cell aggregates presented various shapes. To calculate the sphere size, the diameters of at least 

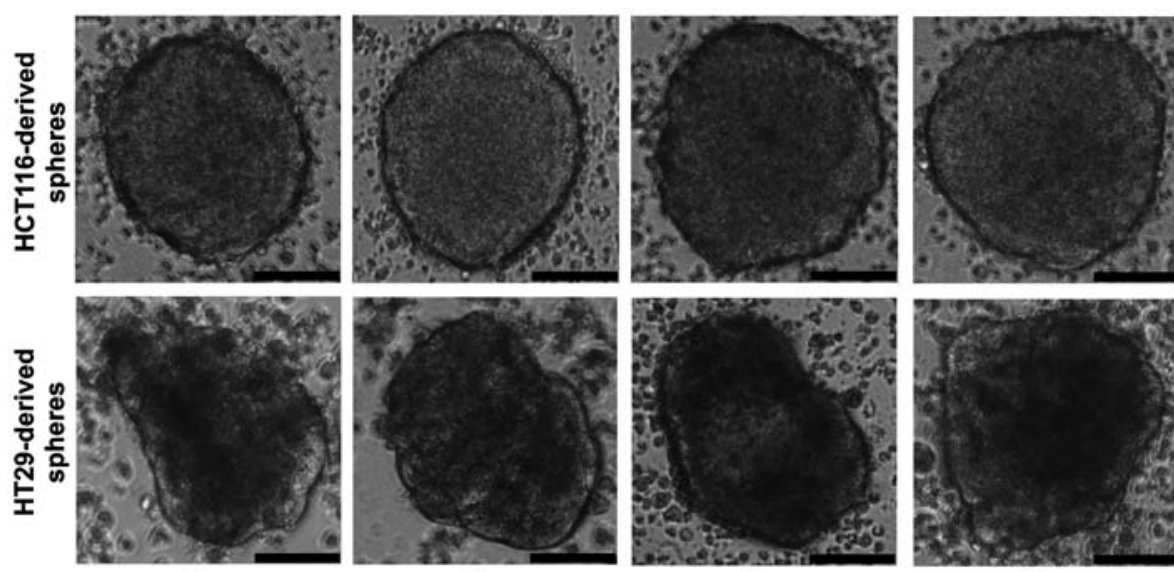

9

11

13

Expansion time (days)

Figure 1. Morphology of colonospheres derived from HCT116 and HT29 cells cultured in SCM. Scale bar, $100 \mu \mathrm{m}$.
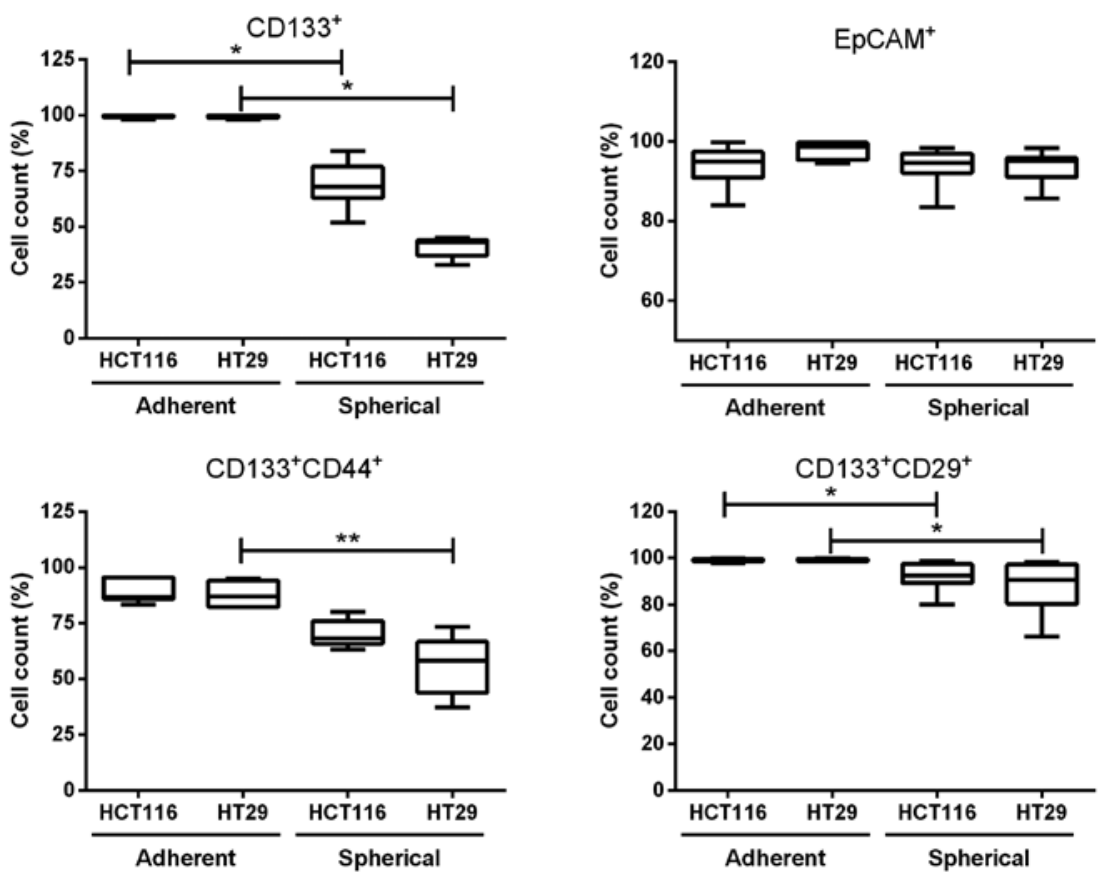

$\mathrm{BMI}-1^{+}$
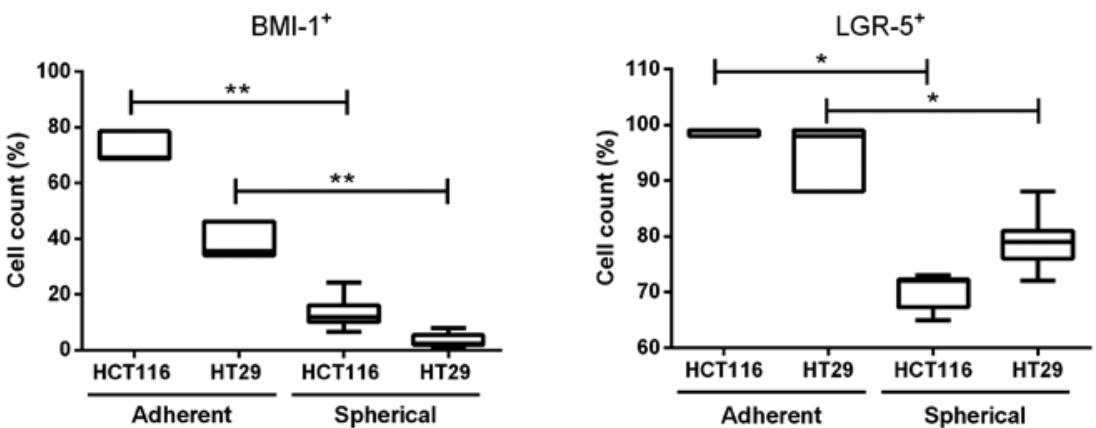

Figure 2. Phenotype of colon cancer cell lines HCT116 and HT29 expanded in adherent and spherical forms. The percentage of cells from colonospheres expressing putative colorectal CSC-like cell markers (CD133, CD44, CD29, EpCAM, LGR-5 and BMI-1) was determined within parental (adherent) and spherical cultures of HCT116 and HT29 cell lines using flow cytometry. The phenotype of colonospheres did not change over the experiments. "P<0.05 and ${ }^{* *} \mathrm{P}<0.001$ indicate statistically significant difference, respectively ( $\mathrm{n}=5$, Kruskal-Wallis ANOVA).

5 representative spheres were measured every second day and the average dimensions of HCT116- and HT29-derived spheres are shown in Table I.
Different expression of CSC-like markers on colonospheres as compared with adherent cell cultures. As CD133 and some other proteins, such as CD44, CD29, BMI-1, LGR-5 


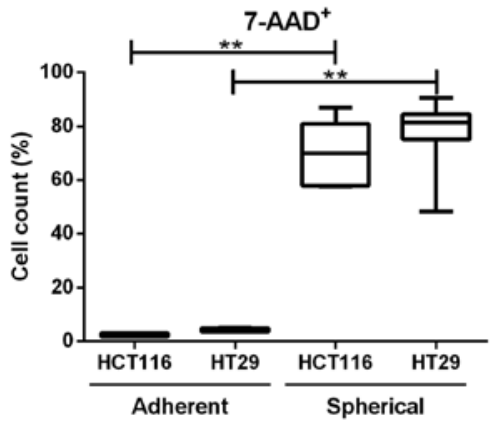

Figure 3. The analysis of viability of cells during expansion time of HCT116 and HT29 CRC lines cultured in adherent and spherical forms. The proportion of 7-AAD ${ }^{+}$cells in cultures. ${ }^{* *} \mathrm{P}<0.001$ indicates statistical significance $(\mathrm{n}=6$, Kruskal-Wallis ANOVA).

and EpCAM, have been reported to be characteristic for CRC-CSC-like cells, we determined their expression by flow cytometry (Fig. 2). We found that adherent forms of HCT116 and HT29 CRC cell lines contained more CSC-like cells than their spherical counterparts. Both parental HCT116 and HT29 cell lines contained $\sim 90 \%$ of $\mathrm{CD} 133^{+} \mathrm{CD} 44^{+}$and $100 \%$ of $\mathrm{CD} 133^{+} \mathrm{CD} 29^{+}$cells. On the contrary, SCs derived from CRC cell lines presented significantly lower number of CD133- CD44 and CD29-positive cells (Fig. 2). The expression of cell adhesion molecule, EpCAM, remained at the same high level during culture expansion time both in adhesive and spherical cultures (Fig. 2). Transformation from adherent to spherical forms of HCT116 and HT29 cell line culture caused decreased expression of some other CSC-like cell markers such as BMI-1 and LGR-5 in comparison to their adherent forms (Fig. 2).

Viability of cells during adhering and colonospheresupporting culture. We evaluated the percentage of non-viable cells in both cell culture systems by flow cytometric assays using 7-AAD dye (Fig. 3), which is excluded by living cells, but binds selectively to GC regions of DNA of damaged cells. The spheres obtained from both studied CRC lines presented significantly higher percentage of non-viable cells than their parental (adherent) cell lines (Fig. 3). To evaluate these observations we analyzed the proportion of 7-AAD ${ }^{+}$cells labeled with Annexin V-FITC and PI by cytometric analysis (data not shown). We confirmed the previous observation that within adherent HCT116 and HT29 lines dead cells constituted only a very minor percentage of the total population, 2 and $3 \%$, respectively. HCT116-derived spheres displayed $64.5 \pm 9.1 \%$ of $7-\mathrm{AAD}^{+}$cells: among them $71.4 \pm 2.5 \%$ constituted lateapoptotic cells, $19.7 \pm 4.2 \%$ presented early apoptotic features and $9.0 \pm 6.1 \%$ were necrotic/dead cells (data not shown). In comparison, 7-AAD ${ }^{+}$cells from spherical model of HT29 were characterized by the presence of $74.7 \pm 5.5 \%$ of late apoptotic and $14.3 \pm 4.9 \%$ of early apoptotic cells, the remaining subpopulation was made up by necrotic/dead cells. The differences between HCT116- and HT29-derived spheres in the proportions of early apoptotic, late apoptotic and necrotic/ death cells were not significant.

Proliferative abilities of cells during adhering and colonosphere-supporting culture. To estimate the proliferative
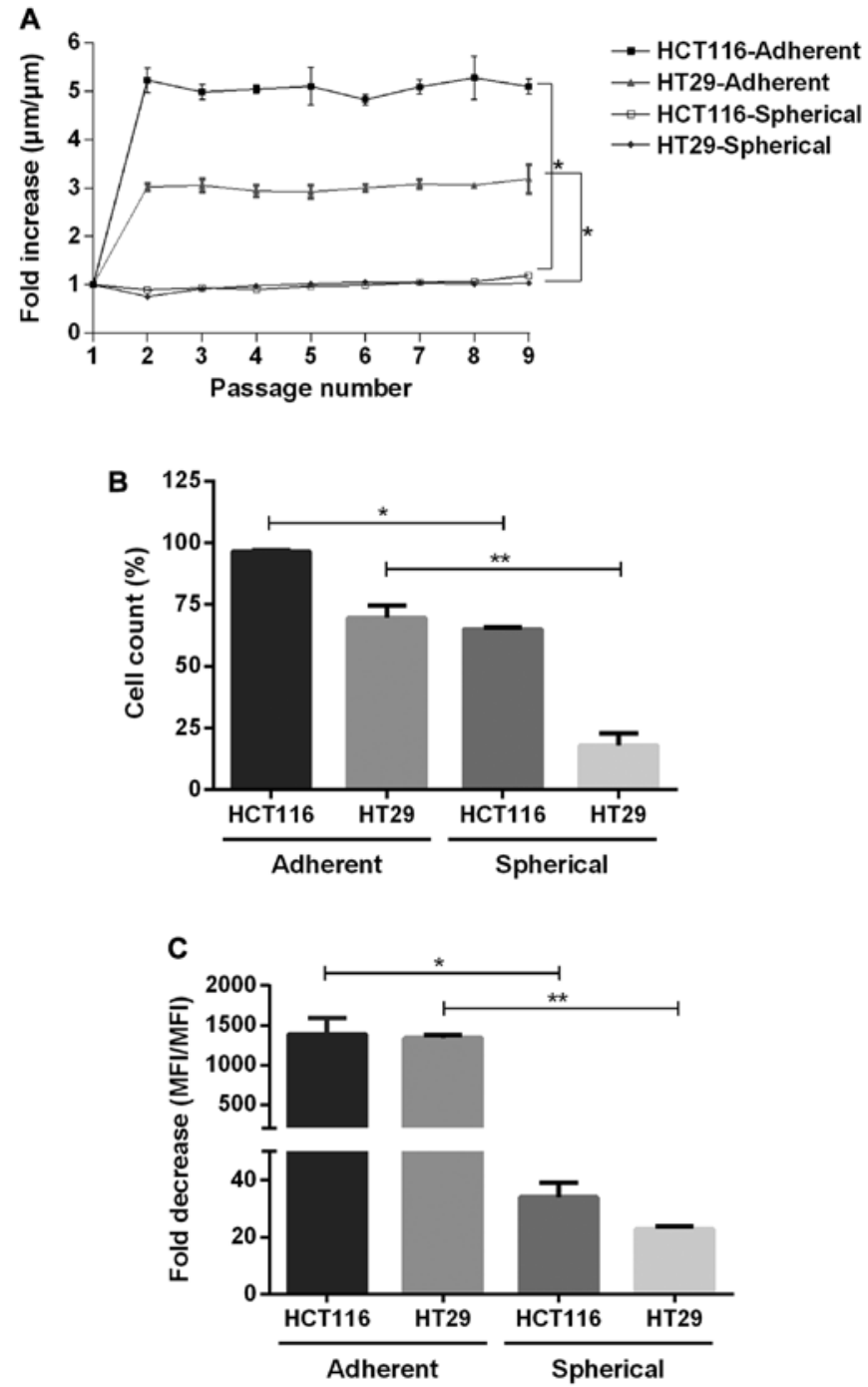

Figure 4. The evaluation of the proliferative abilities of HCT116 and HT29 cells cultured in adherent and spherical forms. (A) Proliferation rates based on the cells growth. (B and C) Proliferative abilities of cellular populations studied with the CellTrace Cell Proliferation kit. (B) The proportions of cells which underwent cellular divisions and presented decreased fluorescence of CFSE dye during incubation time. (C) The fold decrease of CFSE dye median fluorescence intensity (MFI) during incubation time. " $\mathrm{P}<0.05$ or ${ }^{* *} \mathrm{P}<0.001$ indicate statistical significance, respectively ( $\mathrm{n}=6$, Kruskal-Wallis ANOVA).

abilities of SCs cells, we calculated the proliferation rates of cells in both culture systems during every passage (Fig. 4A). In HCT116- or HT29-derived spheres the proliferation rate was 5- or 3-fold lower as compared to the corresponding adherent cells, respectively (Fig. 4A).

The proliferative capacities of cells in adherent and spherical models were also assessed by CFSE-based proliferation assay. CFSE (carboxyfluoresceinsuccinimidyl ester), diffuses into cells and after binding covalently to cellular amine residues, emits fluorescence proportional to the number of stained cells. Changes in CFSE median fluorescence intensity (MFI) after 7 days of incubation compared to the MFI at day 0 represented fold decrease indicative of the rate of proliferation (Fig. 4C). We found $1384 \pm 196$-fold and $1339 \pm 30$-fold MFI decrease in HCT116 and HT29 adherent cell lines, respectively. SCs of the corresponding cell lines presented significantly lower 

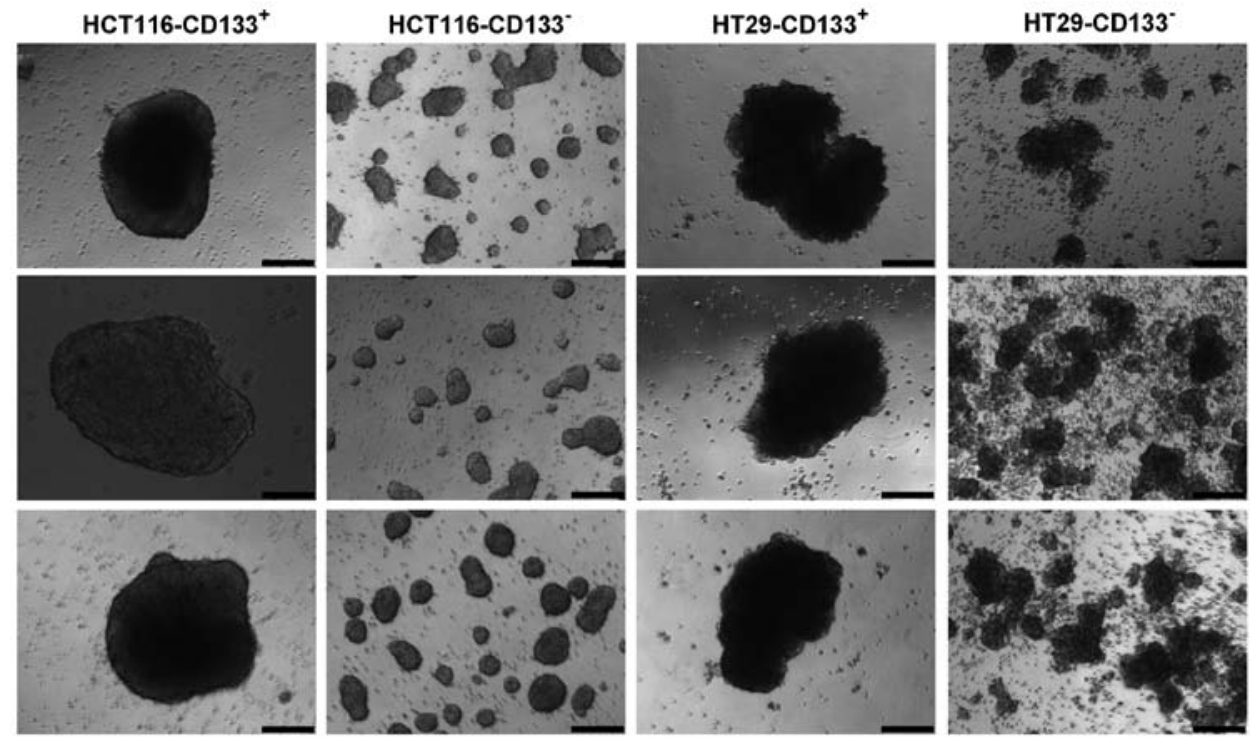

Figure 5. Morphology of HCT116 and HT29 lines after magnetic isolation based on the CD133 expression. All photographs were taken after 7 days of expansion in SCM. Scale bar, $100 \mu \mathrm{m}$.

Table II. Distribution of cells derived from both culture systems in the cell cycle after incubation with PI and flow cytometric analysis.

\begin{tabular}{lcccc}
\hline & G0/G1 & P-value & S/G2/M & P-value \\
\hline HCT116 & $49.5 \pm 4.7 \%$ & $<0.05^{\mathrm{a}}$ & $50.5 \pm 4.7 \%$ & $<0.05^{\mathrm{a}}$ \\
HCT116-derived & $63.6 \pm 9.4 \%$ & & $36.4 \pm 9.4 \%$ & \\
spheres & & & & \\
HT29 & $44.9 \pm 12.9 \%$ & $<0.001^{\mathrm{b}}$ & $55.1 \pm 12.9 \%$ & $<0.001^{\mathrm{b}}$ \\
HT29-derived & $61.4 \pm 6.3 \%$ & & $38.6 \pm 6.3 \%$ & \\
spheres & & & & \\
\hline
\end{tabular}

Cell cycle results expressed as mean \pm SEM. ${ }^{\mathrm{a}} \mathrm{P}<0.001$ or ${ }^{\mathrm{b}} \mathrm{P}<0.001$ indicate statistical significance, respectively $(n=6$, Kruskal-Wallis ANOVA).

MFI fold decrease $(34 \pm 5$ for HCT116-spheres and $23 \pm 1$ for HT29-spheres) between day 0 and 7, indicative of the lower dilution of the CFSE dye and smaller number of cell divisions in spheres as compared to adherent culture (Fig. 4C).

CFSE dye was also used to compare the proportion of cells which underwent divisions to find out how many cells were able to proliferate, thus, how many cells were quiescent. The number of cells with decreased CFSE dye concentration after 7 days of cultivation was estimated (Fig. 4B). Markedly, higher population of cells underwent divisions in HCT116 and HT29 adherent models in comparison to their spherical counterparts. Overall, we confirmed that the SCs had reduced number of cells capable of dividing in comparison to adherent cells.

Cell cycle analysis of cells during adhering and colonosphere-supporting culture. The cell cycle of the adherent- and sphere-forming cells was analyzed by flow cytometry (Table II). Only viable cells were considered since dead cells were gated and not analyzed. We observed significant differences in the proportions of cells in G0/G1 and S/G2/M phases between adherent HCT116 and HT29 cells and their spherical counterparts.

Morphological analysis of the obtained $\mathrm{CDI}^{+} 3^{+}$and $\mathrm{CD} 133$ cells after magnetic separation. To further characterize the putative CSC-like cells of the HCT116 and HT29 cell lines we performed the magnetic sorting based on the expression of the CD133 molecule. Adherent cells from CRC lines were separated into the following fractions: HCT116-CD133 ${ }^{+}$, HCT116-CD133- HT29-CD133+ and HT29-CD133-

After magnetic separation the cell fractions were cultured in the SCM for 14 days and analyzed (Fig. 5). Within the first week, we observed morphological differences between isolated fractions from both studied CRC cell lines. CD133+ subpopulations formed big spheres with apparent contour, similar to their parental floating counterparts, whereas $\mathrm{CD} 133^{-}$cells presented smaller cellular spheres. Additionally, cultures of CD133 cells isolated from HCT116 and HT29 cell lines presented prominent number of cells not involved in sphere formation but just suspended in the medium. Parental spheres and $\mathrm{CD}_{133^{+}}$cell-derived cultures had significantly larger diameter in comparison to their CD133 analogues (Table III).

Phenotype of the obtained $\mathrm{CDI}^{+} 3^{+}$and CD133- cells after magnetic separation. We found that the magneticallyseparated $\mathrm{CD} 133^{+}$fractions from both studied CRC cell lines were enriched in double-positive cells for $\mathrm{CD}_{4} 4^{+}$and $\mathrm{CD} 29^{+}$, whereas CD133- cultures presented significantly increased number of $\mathrm{CD} 44^{-} \mathrm{CD} 29^{+}$cells (Fig. 6A and B). EpCAM expression was similar within all subpopulations, whereas LGR-5 expression was markedly higher in both $\mathrm{CD} 133^{+}$and CD133- subsets derived from HT29 cell line (Fig. 6C), similarly as in the parental populations. However, HCT116-CD133+ and $\mathrm{HT} 29-\mathrm{CD} 133^{+}$populations displayed higher proportion 
Table III. Sizes of spheres formed by separated subsets from 3 independent experiments.

\begin{tabular}{lcccc}
\hline & HCT116-CD133 $^{+}$ & HCT116-CD133 & HT29-CD133 & HT29-CD133- $^{+}$ \\
\hline Length $(\mu \mathrm{m})$ & $231.94 \pm 72.40$ & $97.27 \pm 33.62$ & $235.78 \pm 50.30$ & $83.57 \pm 21.01$ \\
Width $(\mu \mathrm{m})$ & $190.56 \pm 59.00$ & $88.64 \pm 34.45$ & $181.11 \pm 47.47$ & $69.86 \pm 21.30$ \\
\hline
\end{tabular}

At least 5 colonospheres from each experiment were measured. Results are expressed as mean \pm SEM. The diameter of CD133+ derived cultures was significantly greater than in $\mathrm{CD}^{-} 3^{-}$in both $\mathrm{CRC}$ cell lines $(\mathrm{P}<0.001$, Mann-Whitney $\mathrm{U}$ test $)$.
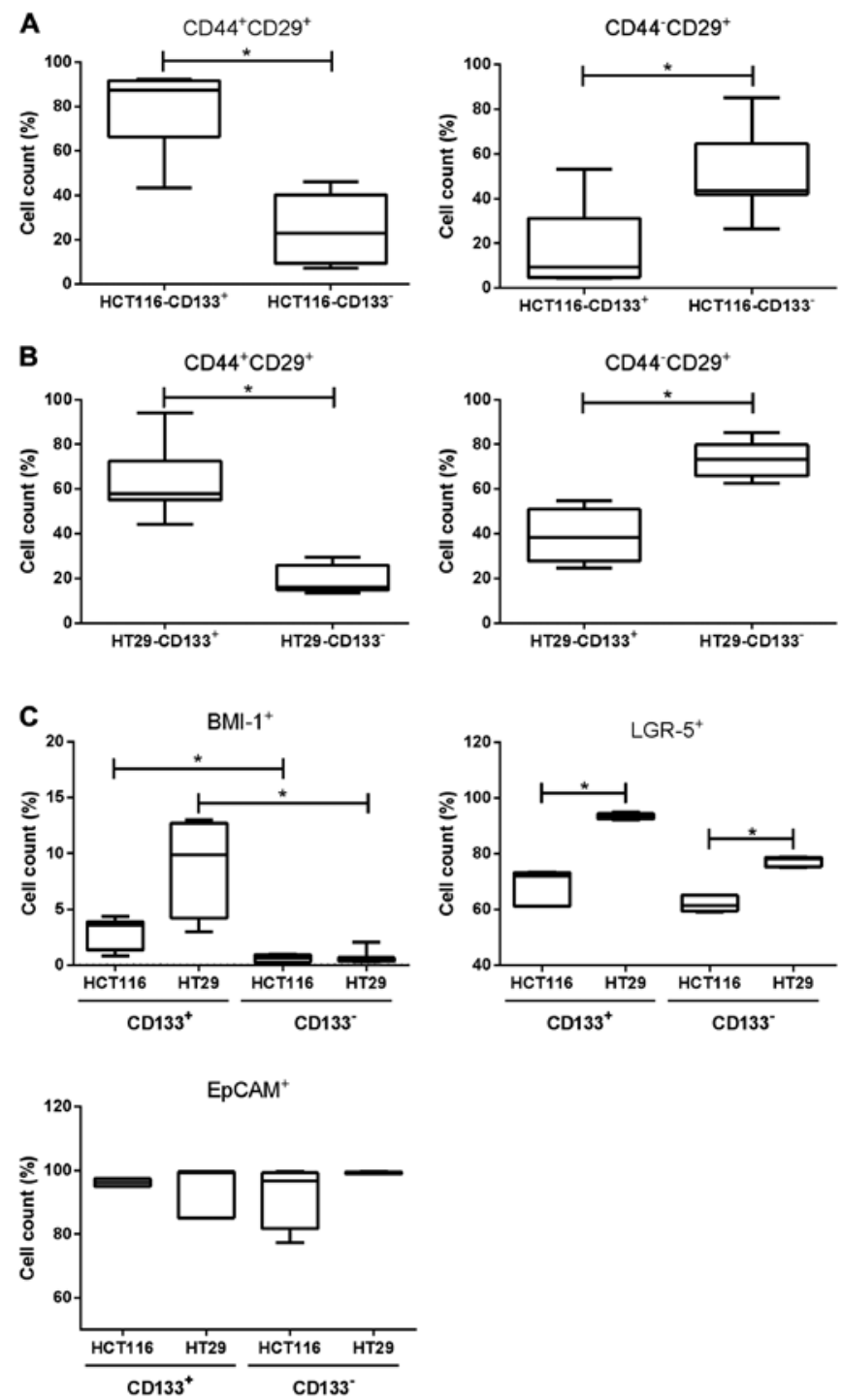

Figure 6. A phenotype of cells after magnetic isolation. (A) The analysis of HCT116-derived subsets based on the presence of CD44 and/or CD29 on their surface. (B) The analysis of HT29-derived subsets based on the presence of CD44 and/or CD29 on their surface. ${ }^{*} \mathrm{P}<0.001$ indicate statistical significance ( $\mathrm{n}=5$, Mann-Whitney $\mathrm{U}$ test). (C) Phenotypic analysis of all cellular fractions based on the presence of LGR-5 and EpCAM on their surface and intracellular BMI-1. ${ }^{*} \mathrm{P}<0.05$ indicates statistical significance $(\mathrm{n}=3$, Kruskal-Wallis ANOVA).

of $\mathrm{BMI}-1^{+}$cells when compared to their CD133-negative analogues (Fig. 6C). The expression of CD44 and CD29 on the cell surface correlated positively with the sphere sizes $(\mathrm{P}<0.05$, $\mathrm{R}=0.28$, Spearman's rank correlation coefficients).
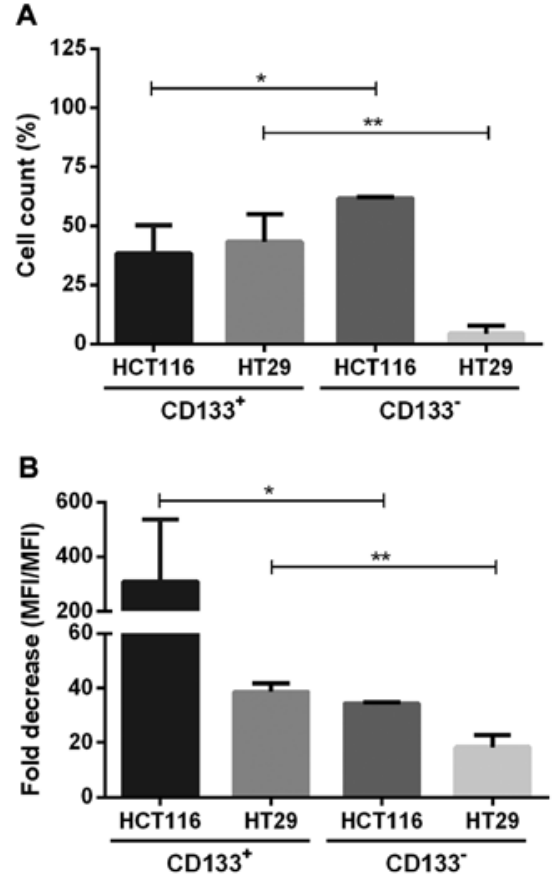

Figure 7. The evaluation of proliferative abilities of sorted cells in $\mathrm{CD}_{133^{+}}$ and CD133 subsets. (A and B) The proliferation of cellular populations was measured with the CellTrace Cell Proliferation kit. (A) The proportion of cells which underwent cellular divisions and presented decreased fluorescence of CFSE dye during incubation time. (B) The fold decrease of CFSE dye median fluorescence intensity (MFI) during incubation time. ${ }^{*} \mathrm{P}<0.05$ or ${ }^{* * *} \mathrm{P}<0.001$ indicate statistical significance, respectively $(\mathrm{n}=4$, Kruskal-Wallis ANOVA).

Viability of the obtained $\mathrm{CD}_{133^{+}}$and $\mathrm{CD} 133^{-}$cells after magnetic separation. The viability and apoptosis of the sorted subpopulations was verified according to the same protocols as we used for original HCT116 and HT29 cells; however, there were no statistical differences between $\mathrm{CD}_{133^{+}}$and CD133 fractions in studied cell lines (data not shown). The detection of dying cells performed with the use of Annexin V-FITC and PI staining did not reveal differences amongst $\mathrm{CD}_{133^{+}}$and CD133- populations from HCT116 and HT29 cell lines and confirmed similar viability of the studied subsets of cells (data not shown).

$\mathrm{CD} 33^{+}$and $\mathrm{CD} 133^{-}$cell fractions have different proliferation rates and dividing potential. The proliferation of $\mathrm{CD}_{13} 3^{+}$and CD133- subpopulations of the studied HC116 and HT29 cells cultured in adherent and spherical models was established by the method of CFSE cell labeling (Fig. 7). HCT116-133 contained significantly higher percentage of proliferating cells, 
A
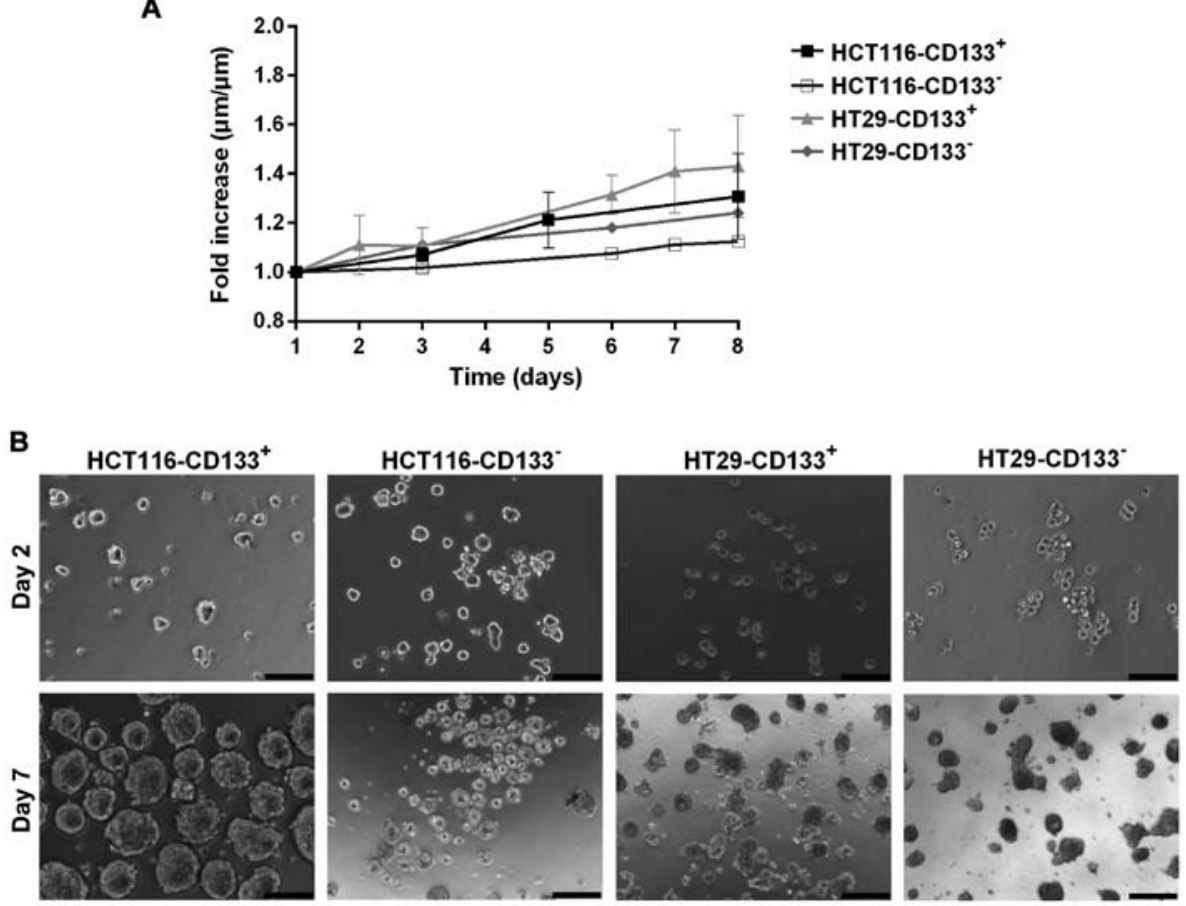

Figure 8. Sphere-formation abilities of $\mathrm{CD}_{133^{+}}$and CD133- fractions derived from HCT116 and HT29 cell lines. (A) Overall sphere growth rate. Spheres were cultured in Matrigel Matrix growth factor reduced matrix for 8 days. Spheres sizes were measured and presented as a fold increase in comparison to their sizes in day 0. (B) $\mathrm{CD}_{133^{+}}$and CD133 subsets derived from CRC cell lines were expanded for 7 days in SCM at concentration $2.5 \times 10^{3}$ cells/well. Sphere-forming ability presented after 2 and 7 days. Scale bar, $100 \mu \mathrm{m}$.
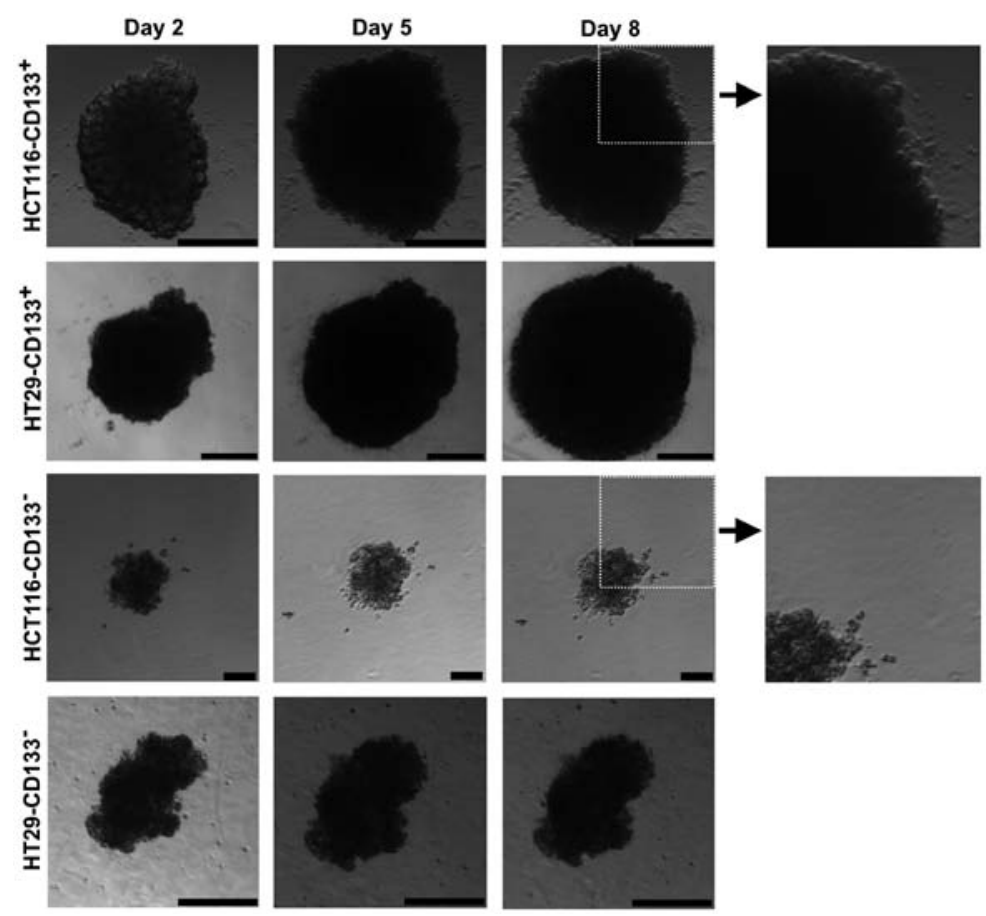

Figure 9. The morphology of spheres cultured in Matrigel Matrix for 8 days. The figure presents the observed outgrowth of one representative sphere from each subpopulation documented at given time-point. Scale bar, $100 \mu \mathrm{m}$.

with decreased amount of CFSE dye in their cytoplasm, indicated as a population with lower MFI in comparison to cells at day 0 (Fig. 7B). Fold decrease measured at day 0 and 7 was $309.3 \pm 119.7 \%$ for HCT116-CD133 ${ }^{+}$, whereas in HT29-CD133 ${ }^{+}$ fraction this value was $38.7 \pm 2.9$ (Fig. 7B). Based on the CFSE fluorescence we assessed the percentage of cells which underwent divisions during expansion (Fig. 7A). Generally, we found that both CRC lines represented different proliferative features because HCT116-CD133 ${ }^{+}$fraction contained higher proportion of actively proliferating cells in comparison to the HCT116-CD133- cells, whereas HT29 cells induced the opposite effects (Fig. 7A). 
Table IV. Distribution of $\mathrm{CD}_{133^{+}}$and CD133- fractions derived from HCT116 and HT29 cell lines in the cell cycle after incubation with PI and flow cytometric analysis.

\begin{tabular}{lcccc}
\hline & G0/G1 & P-value & S/G2/M & P-value \\
\hline HCT116-CD133+ $^{+} 50.8 \pm 2.6 \%$ & $<0.001^{\mathrm{a}}$ & $49.2 \pm 2.6 \%$ & $<0.001^{\mathrm{a}}$ \\
HT29-CD133 $^{+}$ & $39.6 \pm 5.6 \%$ & & $60.4 \pm 5.6 \%$ & \\
HCT116-CD133- $^{-56.8 \pm 2.8 \%}$ & $<0.001^{\mathrm{a}}$ & $43.2 \pm 2.8 \%$ & $<0.001^{\mathrm{a}}$ \\
HT29-CD133- $^{-} 43.7 \pm 4.6 \%$ & & $56.3 \pm 4.6 \%$ & \\
\hline
\end{tabular}

Cell cycle results expressed as mean \pm SEM. ${ }^{\text {a }} \mathrm{P}<0.001$ indicates statistical significance ( $\mathrm{n}=6$, Kruskal-Wallis ANOVA).

Cell cycle analysis of $\mathrm{CD}^{133^{+}}$and CD133- fractions. Staining with PI was performed to establish distribution of sorted fractions of the studied cell lines in the cell cycle, however, we did not observe any significant differences amongst $\mathrm{CD} 133^{+}$and CD133- subpopulations derived from the same CRC cell line. At the same time, we noted changes between same type of fractions isolated from HCT116 and HT29 cells. We observed markedly higher proportion of cells from HCT116-CD133+ in $\mathrm{G} 0 / \mathrm{G} 1$ phase in comparison to $\mathrm{HT} 29-\mathrm{CD}_{133^{+}}$fraction, being 50.8 and $39.6 \%$, respectively. Furthermore, HT29$\mathrm{CD}_{133^{+}}$possessed $60.4 \%$ of actively dividing cells occurring in $\mathrm{S} / \mathrm{G} 2 / \mathrm{M}$ phase whereas this percentage in $\mathrm{CD}_{133^{+}}$subset derived from HCT116 constituted $<50 \%$. When we compared the percentage of $\mathrm{G} 0 / \mathrm{G} 1$ cells amongst fractions from HCT116 and HT29 cell lines, we observed slight increase of quiescent cells in HCT116-133- and HT29-133- subpopulations (Table IV).

The ability to form colonospheres differs between $\mathrm{CD} 133^{+}$ and CD133- subpopulations. Cells from CD133-positive and CD133-negative populations of HCT116 and HT29 cell lines were plated at different cell densities, in range from $2.5 \times 10^{3}$ to 10 cells/well by serial dilution method, in 24 -well plates and cultured for 7 days to evaluate their sphere-formation abilities (spherogenicity). We noticed that both CD133+ and CD133- subpopulations from HCT116 and HT29 lines created spheres at various cell densities (Fig. 8B). Cells after dilution assay were collected to assess their final number in each well after 7 days of incubation (data not shown). We observed rapid increase of cell numbers when they were plated in reduced concentrations what suggested that the cell density influences the cell proliferative capability. Increased number of cells $\left(2.5 \times 10^{3}\right)$ seeded at the beginning of the experiment exhibited inhibitory effect on cellular divisions and their accumulation.

To verify the sphere forming abilities, we also cultured both magnetically separated fractions in Matrigel $^{\mathrm{TM}}$ Matrix for 8 days and calculated their total outgrowth and morphology with microscope equipped with digital camera. We measured the sizes of the growing spheres and afterwards we calculated fold increase by dividing the final size (at day 8) by the value at day 0 of the incubation (Fig. 8A). The trajectory of growth curves fluctuated until day 4, HCT116-CD133+ and HT29-CD133+ increased notably their sizes thereon.
Migration abilities of cells derived from HCT116 cell line. Besides changes in sphere size, cultivating CD133-positive and CD133-negative CRC cell subpopulations in Matrigel ${ }^{\mathrm{TM}}$ Matrix for 8 days showed also structural differences in colonospheres formed by cell fractions from both CRC lines. Cells from all four fractions were able to degrade Matrigel Matrix and enhanced their expansion (Fig. 9). However, only HCT116-derived subpopulations, HCT116-CD133+ and HCT116-CD133-, contained cells with the ability to migrate from parental spheres resulting in irregular outline of spheres and cell presence in distant regions of Matrigel Matrix, suggestive of their invasive properties (Fig. 9).

\section{Discussion}

It has been assumed that 3-D spherical model of the expansion of cancer cells better corresponds with the natural tumor microenvironment and presents properties which may be more relevant to the in vivo tumor development than cancer cell lines cultured in adherent forms (29,36-39). The spherical cultures of cancer cells offer an appropriate model for testing novel anticancer therapeutics, especially those which would target CSC-like cells. It has been recently reported that colonosphere cultures are enriched in CSC-like cells in a cell line-dependent manner, thus, more data are necessary for precise determination of the features of cells forming spherical cultures in each particular cell line (40). Hierarchical model of tumor development has been supported by data for various tumor types including prostate, lung and colon cancers (13,16-18). However, the increased utility of SCs in cancer studies provided divergent results which obscure their real potential and enabled the comparison of data obtained by various research groups. Therefore, the present study aimed to explore the features of colonospheres derived from two commonly used CRC cell lines, HCT116 and HT29, and compare them with the characteristics of the adherent cell cultures. The obtained data present multiple evidence suggesting advantageous use of 3 -D cell cultures in the cancer studies rather than traditional monolayer model.

Our results showed that cultivating human CRC cell lines in spherical forms resulted in harvesting of cells phenotypically different than their adherent counterparts, with an important finding of more in vivo, like diversity creating more reliably environment supporting CSC-like cells for experimental purposes. Thus, colonospheres of the studied cell lines represent more suitable tool for studying in vivo tumor development than adherent cell cultures. Finding of adequate biomarkers for the identification of CSC-like cells is a crucial step to assess the proportion of CSC-like cells within the studied populations. Therefore, apart from the CD133 molecule, which seems to be controversial but still represents the most universal and the most frequently used marker to identify CRC-CSC-like cells many other markers such as CD44, CD166, CD29, CD24, epithelial-specific antigen (ESA), leucine-rich repeat-containing G-protein coupled receptor 5 (LGR-5), B lymphoma Mo-MLV insertion region 1 homolog (BMI-1) have been used for the characterization of CSC-like cells $(22,24,39,41)$. Our results indicated that both cell lines, HCT116 and HT29, when cultured in a selecting, serum-free medium, were able to form freely suspended 
spheres corroborating the results of earlier studies on other CRC lines, including SW1222, Caco-2, SW480, DLD-1 and SW620 $(30,38,42,43)$. However, the wide-ranged characterization and comparison of spherical and adherent forms of the studied CRC cell lines was accomplished first in the present study. Morphologically, HCT116-derived spheres were almost ideally spherical, significantly bigger and had more packed cells than HT29-drived spheres, which presented less regular shapes and 'fuzzy' outlines in contrast to the continuous contours of HCT116 spheres.

The important finding of the present study was the observation of significantly lower ratio of CRC-CSC-like cells, defined by the presence of the CD133, CD44, CD29, LGR-5 and BMI-1 molecules, in SCs of both studied cell lines rather than their adherent counterparts. These results considerably differ from the small fraction of $\mathrm{CD} 133^{+}$cells present in the primary spherical cultures derived from CRC patients $(17,18)$. This discrepancy might have been caused by the use of fresh human tissue resected from CRC patients $(17,18)$, whereas we studied SCs derived from the established CRC cell lines commonly used in experimental studies. Furthermore, data concerning CRC lines are very discrepant. CD133 expression in HCT116 line was found to be greatly diversified. For instance Dittfeld et al (44) showed that in parental HCT116 $\mathrm{CD}_{133}{ }^{+}$cells constituted $74 \%$ and in $3-\mathrm{D}$ model $70 \%$ of all cells, whereas Huang et al (45) reported that 2 and $65 \%$ of cells expressed CD133 in monolayer and colonosphere model, respectively. Some authors reported no differences in percentage of cells positive for CD133 within HT29 CRC line cultured as monolayer and in spherical form (6.25 and 5.6\%, respectively) (46), but others (40) found $\sim 15 \%$ increase of HT29 CD133 ${ }^{+} \mathrm{CD} 44^{+}$cells when cultured under CSC-selective conditions.

Notably, we found that the modification from adherent into spherical form resulted in the major decrease of CD29+ and $\mathrm{CD} 44^{+}$HCT116 and HT29 cells what we associated with the weakening of the junctional complexes between the cells and cell-matrix in spherical cultures (40). Similarly to other authors (47), we found that the expression of the another adhesion molecule, EpCAM, did not differ between CRC cells cultured as monolayer or spheres what suggests that EpCAM is rather a surface marker of colon cancer cells, but not a marker of colon CSC-like cells.

$\mathrm{CRC}$ cell lines were found to present rather high expression of differentiation marker cytokeratin 20 (Ck20) (48), which has been suggested to be a useful diagnostic and prognostic marker in CRC patients $(49,50)$. In line with the idea that SCs should maintain only primitive cells, a concomitant decrease in the percentage of cells expressing $\mathrm{Ck} 20$ was observed in HCT116- and HT29-derived colonospheres (data not shown) in comparison to their adherence counterparts. Moreover, differences within the percentage of $\mathrm{Ck} 20$-positive cells between CRC cell lines correspond with the origin of cell lines, while HCT116-derived cells are less differentiated and more immature, thus, have small fraction of $\mathrm{Ck} 20^{+}$cells, whereas HT29 cell line is less aggressive and possesses greater fraction of cells expressing Ck20.

LGR-5, a target of Wnt signaling, is a marker protein for intestinal stem cells and CSC-like cells, hence it is considered as a potential therapeutic target in colorectal cancer (51-53).
However, it has been recently reported that selective LGR- $5^{+}$ cell ablation curbs primary CRC growth without total tumor regression due to the proliferation of LGR-5 - ells which refilled the LGR- $5^{+}$pool (54). Our finding of decreased proportion of LGR-5 $5^{+}$cells in spherical cultures in comparison to their adherent counterparts could be related to decreased cellcell adhesion as it was found to correlate with the expression of the LGR-5 ${ }^{+}$cells (55). Moreover, this decline might have been affected by the heterogeneity of spherical cultures since they contained lower percentage of $\mathrm{Ck} 20$-expressing cells and higher number of dying cells.

While BMI-1 was reported to play an important role during the self-renewal and maintenance of many types of normal and stem cells, its expression was also analyzed in different types of cancers including leukemia, breast and colorectal (56-58). BMI-1 is thought to protect tumor cells from apoptosis induced by chemotherapeutics but the precise mechanism responsible for its activity is not fully understood $(59,60)$. Although BMI-1 is highly enriched in many types of CSC-like cells, however, not all BMI-1-positive cells are actual CSC-like cells (59). The observations that different subpopulations among CSC-like cells exhibit distinct rate of growth, suggest that BMI-1 should be rather co-expressed with other CSC-like cell markers, including CD133 or CD44 to induce such pro-proliferating effect. The results of the present study seem to support this notion since we found that the expression of BMI-1 was positively correlated with the LGR-5 and CD133 expression in colonospheres. Overall, the phenotypical analysis of the studied CRC cell lines strongly suggests that SCs represented heterogeneous cellular populations at the various development and differentiation stages because of the varied expression of the $\mathrm{LGR}-5^{+}$and $\mathrm{BMI}-1^{+}$markers. $\mathrm{BMI}-1^{+}$cells are rather dormant type of CSC-like cells, which in case of eradication of tumor bulk can be activated by the tumor microenvironment and transform themselves into active, LGR $-5^{+}$cells, form CSC-like cells with regenerative properties, to maintain the balance between the CSC-like populations $(5,60)$.

Importantly, our observation that the viability of cells in 3-D model was significantly lower than in adherent cultures may have an implication for the in vitro studies of cancer cells. According to analysis of phenotype, including LGR-5 and Ck20, and proliferative abilities of cells, we claim that significant percentage of 7-AAD ${ }^{+}$cells within SCs of all studied cell populations (before and after magnetic separation) was the result of cell differentiation and decreased cell-cell interactions. This assumption is in agreement with the findings of other authors who also revealed the ability of immature cells to survive and grow in serum-free suspension, whereas more differentiated cells undergo anoikis, a form of apoptosis triggered by loss of anchorage to ECM elements $(31,61,62)$. What is more, the co-culture of CSC-like with non-CSC-like cells derived from breast cancer lines revealed protective/supporting effect of the latter one toward population with stem traits (62). Despite the elevated percentage of non-viable cells found in colonospheres, the overall number of cells within them was constantly increasing, indicating the presence of continually proliferating cells which prefer SCM culture conditions.

The application of separation based on the CD133 molecule presence on the surface of CRC lines resulted in obtaining cells which could be further cultured, similarly to that found in other 
studies on primary cultures of CRC tumors $(17,18,25,27,29)$ or CRC cell lines $(6,41,44,47)$. Notably, besides changes in the presence of CD133 on the cell surface, obtained fractions presented different proportions of cells bearing other proteins important for the cell-cell and cell-ECM interactions, i.e. CD133 ${ }^{+} \mathrm{CD} 44^{+} \mathrm{CD} 29^{+}$or $\mathrm{CD} 133{ }^{-\mathrm{CD}} 44{ }^{-\mathrm{CD}} 29^{+}$cells, that may affect their sphere-formation ability. We found that spheres formed by both $\mathrm{CD} 133^{+}$cell subsets were significantly smaller than original colonospheres. This indicated that the expansion of 'parental' HCT116- and HT29-derived SCs depended not only on $\mathrm{CD}_{133^{+}}$but also was influenced by $\mathrm{CD} 133^{-}$tumor cells. That is surprising because we noted positive correlation between CD133 proportion and sphere sizes in SCs. Additionally, analysis of dilution assay has shown that both subpopulations from HCT116 and HT29 lines created spheres in SCM independently of number of seeded cells, however, the bigger the concentration of cells, the higher the proliferation rate was. We suppose that sphere formation took place through proliferation and partially also through following aggregation of cells in our experimental settings.

It is widely known that HCT116 and HT29 represent CRC cell lines that correspond to the more and less aggressive forms of this cancer, respectively. Our findings support this important distinction. The analysis of apoptosis based on Annexin V-FITC and PI revealed significant proportion of cells in G0/G1 phase in HCT116-derived SCs indicating presence of dormant cells within the culture, which might contain CSC-like cells, whereas SCs originated from HT29 line presented more cells in active phases of cell cycle, i.e. $\mathrm{S} / \mathrm{G} 2 / \mathrm{M}$. This can be explained by differences in the derivation of cell lines as HCT116 line represent non-differentiated and highly aggressive cell line that corresponds to the TNM 3 stage, so we assume that number of CSC-like cells could be higher than in HT29 line, which is known as less invasive (TNM 2). However, subsets obtained after magnetic isolation possessed approximately similar percentage of cells in G0/G1 and $\mathrm{S} / \mathrm{G} 2 / \mathrm{M}$ as their parental spherical counterparts, thus, linage-dependent factors influence the cell cycle features of cells during their expansion in culture, especially in spherical forms.

The analysis of the proliferative potential of the analyzed cell types revealed, as we expected, that adherent CRC lines showed significantly higher proliferation rates than their spherical counterparts. This can be associated with the phenotypical heterogeneity of the culture forms of the studied CRC cell lines. Since colonospheres presented lower proportion of CSC-like cells, lower proliferative potential and higher proportion of dead/dying cells in culture we suggests that SCs of cancer cells better mimic the properties of primary CRC tumors. Therefore, colonospheres should be more widely used for the studies of cancer, e.g. such as ex vivo evaluation of chemotherapeutics.

The magnetic separation of cells from CRC cell lines with different expression of CSC-like cell markers provides another useful tool for the in vitro studies. In this respect, the choice of CD133 molecule, a putative marker of CSC-like cells, enabled us to isolate from colonospheres cell populations with different proliferative capacities. For instance, HCT116-CD133+ cells as compared with HCT116-CD133 cells contained quite small fraction of cells which underwent divisions during incubation time but presented much higher proliferative potential, and these parameters were even more obvious in HT29-CD133+. These observations were confirmed by the dilution assays which showed that $\mathrm{CD} 133^{+}$ cell fractions derived from both CRC lines proliferated more frequently and formed more prominent spheres than CD133 cells. The finding that $\mathrm{CD} 133^{+}$cells seem to possess high colony-formation ability should be used in the future studies of colonospheres, especially those which investigate targeted chemotherapy of CRC cells.

Overexpression of transcription factors inducing EMT is associated with induction of stemness amongst cancer cells suggesting the connection between EMT and CSC-like cells, thereby revealing that those cells do not have to remain in their static state but are dynamic instead $(4,63)$. MerlosSuarez et al (64) associated CSC-like cells with metastasis and suggested that metastasizing cells may obtain CSC-like cell traits while expand tumor region and invasion. The use of Matrigel Matrix, a natural complex hydrogel of ECM proteins and associated components such as laminin, type IV collagen, entactin, and heparin sulphate $(65,66)$, enabled us to assess the invasive capacities of $\mathrm{CD} 133^{+}$and $\mathrm{CD} 133^{-}$derived from HT29 and HCT116 cell lines. We observed large number of cells leaving spheres during expansion in Matrigel Matrix from both HCT116-CD133+ and HCT116-CD133- fractions proving their aggressive properties and invasiveness. Notably, we are probably the first to report that the cells of $\mathrm{HT} 29-\mathrm{CD} 133^{+}$- and HT29-CD133-derived colonospheres did not present invasive properties since they were not capable to leave the abandon maternal sphere. This can be explained by the fact that HT29 cells were originally isolated from primary, not metastatic tumor and represent lower, II stage, whereas HCT116 cells are placed in III class in the TNM classification. However, since the HT29-CD133 ${ }^{+}$and HT29-CD133-derived spheres could increase in size, similarly to the HCT116 counterparts, we assumed that they were able to degrade Matrigel Matrix. This finding provided further evidence that the colonospheres present a better model for the in vitro studies of cancer cells than the adherent cell cultures.

It is noticeable that there are many epigenetic and genetic features which differ in HCT116 and HT29 cells and might have influenced the presented results. HCT116 cells were originally isolated from primary tumor derived from colon ascendens of 48-year-old male $(67,68)$, whereas HT29 cell lines represents human colonic adenocarcinoma originating from 44-yearold female (69). Ahmed et al (70) explored the genetic and epigenetic molecular phenotype of 24 colon cancer cell lines, including HCT116 and HT29. Cells from these lines possessed different status of one of the most commonly mutated genes in colon cancer, KRAS. HT29 has wild-type of KRAS $\left(K R A S^{W T}\right)$, while HCT116 gained mutated $K R A S^{G 13 D}(70)$, which resulted in a constitutive activation of KRAS signaling pathway. In this pathway the RAS protein plays an important role as central mediator downstream of growth factor receptors and therefore, it is critical for cell proliferation, survival, and differentiation involving mitogen-activated protein kinases (MAPKs) and phosphoinositide-3 kinase (PI3K) pathways $(71,72)$. Cells harboring KRAS mutations within codon 13 are reported to possess high oncogenic potential and be very aggressive (73). Additionally, KRAS status has also biological relevance in 
terms of colorectal cancer clinical outcome to anti-EGFR therapy (74) and senescence and/or apoptosis mediated by FasR/FasL (75,76). Besides KRAS gene, HCT116 and HT29 cell lines represent different mutation status of chromosomal instability (CIN) phenotype and some cancer critical genes such as BRAF, PIK3CA and TP53 genes (70). Some of these genes might be used for prediction of clinical benefit from anti-EGFR treatment in metastatic colorectal cancer (77), hence the usage of HCT116 and HT29 cell lines allows for comparison of broad spectrum of features characteristic for these types of cells.

When it comes to the relations of our results to the genetic status of both used CRC lines, we could only suspect that the deregulation and constant activation of EGFR pathway (due to mutated form of KRAS gene) may influence the proliferative abilities, phenotype of cells and growth of spheres. However, if such features are directly associated with one mutation or rather with general cancer progression status remains unclear and requires more studies.

Undeniably, 2-D immortalized CRC cell lines represent elegant model to extend the knowledge concerning cell transformation. However, they will never provide adequate culture to analyze elaborated tumor biology in vivo, which seems to be more reliably mimicked by the spherical culture system as was postulated earlier by others $(28-30,35,37)$ and as we concluded from the presented study. Cells cultured under CSC-supporting conditions seem to share more similarities with original tumors, indicating that they provide a more biologically relevant culture system when compared with widely used traditional monolayer cultures, including the lower proportion of CSC-like cells. Therefore, we claim that 3-D spherical model of CRC lines should be considered as an important tool for the in vitro studies of cancer, especially these which target non-differentiated CSC-like cells and their microenvironment.

\section{Acknowledgements}

The present study was supported by a grant from the Polish Ministry of Science and Higher Education, contract grants number: MN 01-0232/08/280 and N N402 684040.

\section{References}

1. Manhas J, Bhattacharya A, Agrawal SK, Gupta B, Das P, Deo SV, $\mathrm{Pal} S$ and Sen S: Characterization of cancer stem cells from different grades of human colorectal cancer. Tumour Biol 37 : 14069-14081, 2016.

2. Zeuner A, Todaro M, Stassi G and De Maria R: Colorectal cancer stem cells: From the crypt to the clinic. Cell Stem Cell 15: 692-705, 2014.

3. Farhana L, Nangia-Makker P, Arbit E, Shango K, Sarkar S, Mahmud H, Hadden T, Yu Y and Majumdar AP: Bile acid: A potential inducer of colon cancer stem cells. Stem Cell Res Ther 7: 181, 2016.

4. Oshima N, Yamada Y, Nagayama S, Kawada K, Hasegawa S, Okabe H, Sakai Y and Aoi T: Induction of cancer stem cell properties in colon cancer cells by defined factors. PLoS One 9: e101735, 2014.

5. Pan T, Xu J and Zhu Y: Self-renewal molecular mechanisms of colorectal cancer stem cells. Int J Mol Med 39: 9-20, 2017.

6. Yang G, Quan Y, Wang W, Fu Q, Wu J, Mei T, Li J, Tang Y, Luo C, Ouyang Q, et al: Dynamic equilibrium between cancer stem cells and non-stem cancer cells in human SW620 and MCF-7 cancer cell populations. Br J Cancer 106: 1512-1519, 2012.
7. Lapidot T, Sirard C, Vormoor J, Murdoch B, Hoang T, Caceres-Cortes J, Minden M, Paterson B, Caligiuri MA and Dick JE: A cell initiating human acute myeloid leukaemia after transplantation into SCID mice. Nature 367: 645-648, 1994.

8. Al-Hajj M, Wicha MS, Benito-Hernandez A, Morrison SJ and Clarke MF: Prospective identification of tumorigenic breast cancer cells. Proc Natl Acad Sci USA 100: 3983-3988, 2003.

9. Charafe-Jauffret E, Ginestier C, Iovino F, Wicinski J, Cervera N, Finetti P, Hur MH, Diebel ME, Monville F, Dutcher J, et al: Breast cancer cell lines contain functional cancer stem cells with metastatic capacity and a distinct molecular signature. Cancer Res 69: 1302-1313, 2009.

10. Hermann PC, Huber SL, Herrler T, Aicher A, Ellwart JW, Guba M, Bruns CJ and Heeschen C: Distinct populations of cancer stem cells determine tumor growth and metastatic activity in human pancreatic cancer. Cell Stem Cell 1: 313-323, 2007.

11. Li C, Lee CJ and Simeone DM: Identification of human pancreatic cancer stem cells. Methods Mol Biol 568: 161-173, 2009.

12. Fang D, Nguyen TK, Leishear K, Finko R, Kulp AN, Hotz S, Van Belle PA, Xu X, Elder DE and Herlyn M: A tumorigenic subpopulation with stem cell properties in melanomas. Cancer Res 65: 9328-9337, 2005.

13. Kim CF, Jackson EL, Woolfenden AE, Lawrence S, Babar I, Vogel S, Crowley D, Bronson RT and Jacks T: Identification of bronchioalveolar stem cells in normal lung and lung cancer. Cell 121: 823-835, 2005.

14. Liu G, Yuan X, Zeng Z, Tunici P, Ng H, Abdulkadir IR, Lu L, Irvin D, Black KL and Yu JS: Analysis of gene expression and chemoresistance of $\mathrm{CD} 133^{+}$cancer stem cells in glioblastoma. Mol Cancer 5: 67, 2006.

15. Gilbertson RJ and Rich JN: Making a tumour's bed: Glioblastoma stem cells and the vascular niche. Nat Rev Cancer 7: 733-736, 2007.

16. Collins AT, Berry PA, Hyde C, Stower MJ and Maitland NJ: Prospective identification of tumorigenic prostate cancer stem cells. Cancer Res 65: 10946-10951, 2005.

17. Ricci-Vitiani L, Lombardi DG, Pilozzi E, Biffoni M, Todaro M, Peschle $C$ and De Maria R: Identification and expansion of human colon-cancer-initiating cells. Nature 445: 111-115, 2007.

18. O'Brien CA, Pollett A, Gallinger S and Dick JE: A human colon cancer cell capable of initiating tumour growth in immunodeficient mice. Nature 445: 106-110, 2007.

19. Singh SK, Clarke ID, Terasaki M, Bonn VE, Hawkins C, Squire J and Dirks PB: Identification of a cancer stem cell in human brain tumors. Cancer Res 63: 5821-5828, 2003.

20. Singh SK, Hawkins C, Clarke ID, Squire JA, Bayani J, Hide T, Henkelman RM, Cusimano MD and Dirks PB: Identification of human brain tumour initiating cells. Nature 432: 396-401, 2004.

21. Dragu DL, Necula LG, Bleotu C, Diaconu CC and ChivuEconomescu M: Therapies targeting cancer stem cells: Current trends and future challenges. World J Stem Cells 7: 1185-1201, 2015.

22. Chen K, Huang YH and Chen JL: Understanding and targeting cancer stem cells: Therapeutic implications and challenges. Acta Pharmacol Sin 34: 732-740, 2013.

23. Touil Y, Igoudjil W, Corvaisier M, Dessein AF, Vandomme J, Monté D, Stechly L, Skrypek N, Langlois C, Grard G, et al: Colon cancer cells escape 5FU chemotherapy-induced cell death by entering stemness and quiescence associated with the c-Yes/ YAP axis. Clin Cancer Res 20: 837-846, 2014.

24. Islam F, Gopalan V, Smith RA and Lam AK: Translational potential of cancer stem cells: A review of the detection of cancer stem cells and their roles in cancer recurrence and cancer treatment. Exp Cell Res 335: 135-147, 2015.

25. Fang DD, Kim YJ, Lee CN, Aggarwal S, McKinnon K, Mesmer D, Norton J, Birse CE, He T, Ruben SM, et al: Expansion of CD133+ colon cancer cultures retaining stem cell properties to enable cancer stem cell target discovery. Br J Cancer 102: 1265-1275, 2010.

26. Li Z: CD133: A stem cell biomarker and beyond. Exp Hematol Oncol 2: 17, 2013.

27. Shmelkov SV, Butler JM, Hooper AT, Hormigo A, Kushner J, Milde T, St Clair R, Baljevic M, White I, Jin DK, et al: CD133 expression is not restricted to stem cells, and both $\mathrm{CD}_{133^{+}}$and CD133- metastatic colon cancer cells initiate tumors. J Clin Invest 118: 2111-2120, 2008.

28. Weiswald LB, Bellet D and Dangles-Marie V: Spherical cancer models in tumor biology. Neoplasia 17: 1-15, 2015. 
29. Qureshi-Baig K, Ullmann P, Rodriguez F, Frasquilho S, Nazarov PV, Haan S and Letellier E: What do we learn from spheroidculture systems? Insights from tumorspheres derived from primary colon cancer tissue. PLoS One 11: e0146052, 2016.

30. Collura A, Marisa L, Trojan D, Buhard O, Lagrange A, Saget A, Bombled M, Méchighel P, Ayadi M, Muleris M, et al: Extensive characterization of sphere models established from colorectal cancer cell lines. Cell Mol Life Sci 70: 729-742, 2013.

31. Weiswald LB, Richon S, Massonnet G, Guinebretière JM, Vacher S, Laurendeau I, Cottu P, Marangoni E, Nemati F, Validire $\mathrm{P}$, et al: A short-term colorectal cancer sphere culture as a relevant tool for human cancer biology investigation. Br J Cancer 108: 1720-1731, 2013.

32. Chandrasekaran S, Marshall JR, Messing JA, Hsu JW and King MR: TRAIL-mediated apoptosis in breast cancer cells cultured as 3D spheroids. PLoS One 9: e111487, 2014.

33. Endo H, Okami J, Okuyama H, Kumagai T, Uchida J, Kondo J, Takehara T, Nishizawa Y, Imamura F, Higashiyama M, et al: Spheroid culture of primary lung cancer cells with neuregulin 1/HER3 pathway activation. J Thorac Oncol 8: 131-139, 2013.

34. Tong JG, Valdes YR, Barrett JW, Bell JC, Stojdl D, McFadden G, McCart JA, DiMattia GE and Shepherd TG: Evidence for differential viral oncolytic efficacy in an in vitro model of epithelial ovarian cancer metastasis. Mol Ther Oncolytics 2: 15013, 2015.

35. Hirschhaeuser F, Menne H, Dittfeld C, West J, Mueller-Klieser W and Kunz-Schughart LA: Multicellular tumor spheroids: An underestimated tool is catching up again. J Biotechnol 148: 3-15, 2010.

36. Nath S and Devi GR: Three-dimensional culture systems in cancer research: Focus on tumor spheroid model. Pharmacol Ther 163: 94-108, 2016.

37. Lee SH, Hong JH, Park HK, Park JS, Kim BK, Lee JY, Jeong JY, Yoon GS, Inoue M, Choi GS, et al: Colorectal cancer-derived tumor spheroids retain the characteristics of original tumors. Cancer Lett 367: 34-42, 2015.

38. Stankevicius V, Kunigenas L, Stankunas E, Kuodyte K, Strainiene E, Cicenas J, Samalavicius NE and Suziedelis K The expression of cancer stem cell markers in human colorectal carcinoma cells in a microenvironment dependent manner. Biochem Biophys Res Commun 484: 726-733, 2017.

39. Vermeulen L, Todaro M, de Sousa Mello F, Sprick MR, Kemper K, Perez Alea M, Richel DJ, Stassi G and Medema JP: Single-cell cloning of colon cancer stem cells reveals a multilineage differentiation capacity. Proc Natl Acad Sci USA 105: 13427-13432, 2008

40. Calvet CY, André FM and Mir LM: The culture of cancer cell lines as tumorspheres does not systematically result in cancer stem cell enrichment. PLoS One 9: e89644, 2014.

41. Botchkina IL, Rowehl RA, Rivadeneira DE, Karpeh MS Jr, Crawford H, Dufour A, Ju J, Wang Y, Leyfman Y and Botchkina GI: Phenotypic subpopulations of metastatic colon cancer stem cells: Genomic analysis. Cancer Genomics Proteomics 6: 19-29, 2009.

42. Shaheen S, Ahmed M, Lorenzi F and Nateri AS: Spheroidformation (Colonosphere) assay for in vitro sssessment and expansion of stem cells in colon cancer. Stem Cell Rev 12: 492-499, 2016.

43. Yeung TM, Gandhi SC, Wilding JL, Muschel R and Bodmer WF: Cancer stem cells from colorectal cancer-derived cell lines. Proc Natl Acad Sci USA 107: 3722-3727, 2010.

44. Dittfeld C, Dietrich A, Peickert S, Hering S, Baumann M, Grade M, Ried T and Kunz-Schughart LA: CD133 expression is not selective for tumor-initiating or radioresistant cell populations in the CRC cell lines HCT-116. Radiother Oncol 92: 353-361, 2009.

45. Huang R, Wang G, Song Y, Tang Q, You Q, Liu Z, Chen Y, Zhang Q, Li J, Muhammand S, et al: Colorectal cancer stem cell and chemoresistant colorectal cancer cell phenotypes and increased sensitivity to Notch pathway inhibitor. Mol Med Rep 12: 2417-2424, 2015

46. Fan X, Ouyang N, Teng $\mathrm{H}$ and Yao H: Isolation and characterization of spheroid cells from the HT29 colon cancer cell line. Int J Colorectal Dis 26: 1279-1285, 2011

47. Wang C, Xie J, Guo J, Manning HC, Gore JC and Guo N: Evaluation of CD44 and CD133 as cancer stem cell markers for colorectal cancer. Oncol Rep 28: 1301-1308, 2012.

48. Chan CW, Wong NA, Liu Y, Bicknell D, Turley H, Hollins L, Miller CJ, Wilding JL and Bodmer WF: Gastrointestinal differentiation marker Cytokeratin 20 is regulated by homeobox gene CDX1. Proc Natl Acad Sci USA 106: 1936-1941, 2009.
49. Ning Y, Hanna DL, Zhang W, Mendez A, Yang D, El-Khoueiry R Matsusaka S, Sunakawa Y, Stremitzer S, Parekh A, et al: Cytokeratin-20 and survivin-expressing circulating tumor cells predict survival in metastatic colorectal cancer patients by a combined immunomagnetic qRT-PCR approach. Mol Cancer Ther 14: 2401-2408, 2015.

50. Imai Y, Yamagishi H, Fukuda K, Okamura T, Ono Y, Ban S, Inoue T and Ueda Y: Expression of cytokeratin 20 indicates invasive histological phenotype in poorly differentiated colorectal adenocarcinoma. Anticancer Res 34: 159-167, 2014.

51. Yanai H, Atsumi N, Tanaka T, Nakamura N, Komai Y, Omachi T, Tanaka K, Ishigaki K, Saiga K, Ohsugi H, et al: Intestinal cancer stem cells marked by Bmil or Lgr5 expression contribute to tumor propagation via clonal expansion. Sci Rep 7: 41838, 2017.

52. Shimokawa M, Ohta Y, Nishikori S, Matano M, Takano A, Fujii M, Date S, Sugimoto S, Kanai T and Sato T: Visualization and targeting of $\mathrm{LGR}^{+}$human colon cancer stem cells. Nature 545: 187-192, 2017.

53. Hirsch D, Barker N, McNeil N, Hu Y, Camps J, McKinnon K, Clevers H, Ried $\mathrm{T}$ and Gaiser T: LGR5 positivity defines stem-like cells in colorectal cancer. Carcinogenesis 35: 849-858, 2014.

54. de Sousa e Melo F, Kurtova AV, Harnoss JM, Kljavin N, Hoeck JD, Hung J, Anderson JE, Storm EE, Modrusan Z, Koeppen H, et al: A distinct role for $\mathrm{Lgr}^{+}$stem cells in primary and metastatic colon cancer. Nature 543: 676-680, 2017.

55. Walker F, Zhang HH, Odorizzi A and Burgess AW: LGR5 is a negative regulator of tumourigenicity, antagonizes Wnt signalling and regulates cell adhesion in colorectal cancer cell lines. PLoS One 6: e22733, 2011.

56. Parvathi MV, Murthy PB, Vennila M and Suresh BV: Regulation of BMI1 Polycomb gene expression in histological grades of invasive ductal breast carcinomas and its correlation with hormone receptor status. Tumour Biol 34: 3807-3815, 2013.

57. Peng HX, Liu XD, Luo ZY, Zhang XH, Luo XQ, Chen X, Jiang H and $\mathrm{Xu} \mathrm{L}$ : Upregulation of the proto-oncogene Bmi-1 predicts a poor prognosis in pediatric acute lymphoblastic leukemia. BMC Cancer 17: 76, 2017

58. Li X, Zheng X, Xu B, Zhang D, Xu Y, Xie Q, Hu W, Zheng Z, Shao Y, Wu J, et al: Lower Bmi-1 expression may predict longer survival of colon cancer patients. Cell Physiol Biochem 39: 2421-2426, 2016.

59. Siddique HR and Saleem M: Role of BMI1, a stem cell factor, in cancer recurrence and chemoresistance: Preclinical and clinical evidences. Stem Cells 30: 372-378, 2012.

60. Yan KS, Chia LA, Li X, Ootani A, Su J, Lee JY, Su N, Luo Y, Heilshorn SC, Amieva MR, et al: The intestinal stem cell markers Bmil and Lgr5 identify two functionally distinct populations. Proc Natl Acad Sci USA 109: 466-471, 2012.

61. Charafe-Jauffret E, Monville F, Ginestier C, Dontu G, Birnbaum D and Wicha MS: Cancer stem cells in breast: Current opinion and future challenges. Pathobiology 75: 75-84, 2008.

62. Kim SY, Hong SH, Basse PH, Wu C, Bartlett DL, Kwon YT and Lee YJ: Cancer stem cells protect non-stem cells from anoikis: bystander effects. J Cell Biochem 117: 2289-2301, 2016.

63. Sato R, Semba T, Saya H and Arima Y: Concise Review: Stem cells and epithelial-mesenchymal transition in cancer: Biological implications and therapeutic targets. Stem Cells 34: 1997-2007, 2016.

64. Merlos-Suárez A, Barriga FM, Jung P, Iglesias M, Céspedes MV, Rossell D, Sevillano M, Hernando-Momblona X, da Silva-Diz V, Muñoz $\mathrm{P}$, et al: The intestinal stem cell signature identifies colorectal cancer stem cells and predicts disease relapse. Cell Stem Cell 8: 511-524, 2011.

65. Albini A and Noonan DM: The 'chemoinvasion' assay, 25 years and still going strong: The use of reconstituted basement membranes to study cell invasion and angiogenesis. Curr Opin Cell Biol 22: 677-689, 2010

66. Benton G, Arnaoutova I, George J, Kleinman HK and Koblinski J: Matrigel: From discovery and ECM mimicry to assays and models for cancer research. Adv Drug Deliv Rev 79-80: 3-18, 2014.

67. Brattain MG, Brattain DE, Fine WD, Khaled FM, Marks ME, Kimball PM, Arcolano LA and Danbury BH: Initiation and characterization of cultures of human colonic carcinoma with different biological characteristics utilizing feeder layers of confluent fibroblasts. Oncodev Biol Med 2: 355-366, 1981.

68. Brattain MG, Fine WD, Khaled FM, Thompson J and Brattain DE: Heterogeneity of malignant cells from a human colonic carcinoma. Cancer Res 41: 1751-1756, 1981. 
69. Fogh J and Trempe G: New human tumor cell lines. In: Human Tumor Cells in Vitro. Fogh J (ed). Springer US, Boston, MA, pp115-159, 1975.

70. Ahmed D, Eide PW, Eilertsen IA, Danielsen SA, Eknæs M, Hektoen M, Lind GE and Lothe RA: Epigenetic and genetic features of 24 colon cancer cell lines. Oncogenesis 2: e71, 2013.

71. Aksamitiene E, Kiyatkin A and Kholodenko BN: Cross-talk between mitogenic Ras/MAPK and survival PI3K/Akt pathways: A fine balance. Biochem Soc Trans 40: 139-146, 2012.

72. Zenonos K and Kyprianou K: RAS signaling pathways, mutations and their role in colorectal cancer. World J Gastrointest Oncol 5: 97-101, 2013.

73. Bazan V, Migliavacca M, Zanna I, Tubiolo C, Grassi N, Latteri MA, La Farina M, Albanese I, Dardanoni G, Salerno S, et al: Specific codon $13 \mathrm{~K}$-ras mutations are predictive of clinical outcome in colorectal cancer patients, whereas codon $12 \mathrm{~K}$-ras mutations are associated with mucinous histotype. Ann Oncol 13: 1438-1446, 2002.
74. Knickelbein K and Zhang L: Mutant KRAS as a critical determinant of the therapeutic response of colorectal cancer. Genes Dis 2: 4-12, 2015.

75. Raats DA, Frenkel N, van Schelven SJ, Rinkes IH, Laoukili J and Kranenburg O: CD95 ligand induces senescence in mismatch repair-deficient human colon cancer via chronic caspase-mediated induction of DNA damage. Cell Death Dis 8: e2669, 2017.

76. Szarynska M, Olejniczak A, Wierzbicki P, Kobiela J, Laski D, Sledzinski Z, Adrych K, Guzek M and Kmiec Z: FasR and FasL in colorectal cancer. Int J Oncol 51: 975-986, 2017.

77. Therkildsen C, Bergmann TK, Henrichsen-Schnack T, Ladelund $\mathrm{S}$ and Nilbert M: The predictive value of KRAS, NRAS, $B R A F, P I K 3 C A$ and PTEN for anti-EGFR treatment in metastatic colorectal cancer: A systematic review and meta-analysis. Acta Oncol 53: 852-864, 2014. 